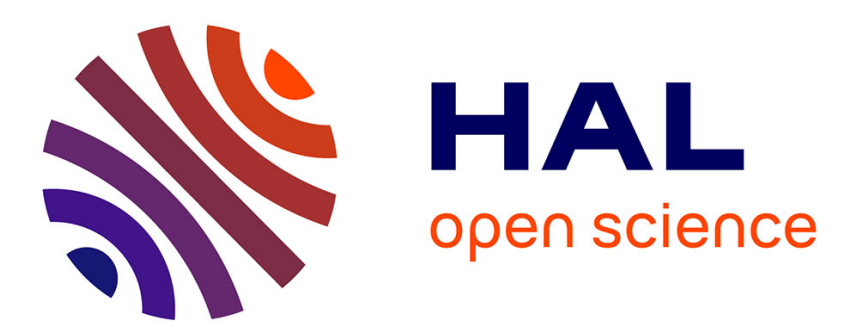

\title{
13C and 14C evidence of pollution of a soil by fossil fuel and reconstruction of the composition of the polluant
}

Eric Lichtfouse, Timothy Eglinton

\section{To cite this version:}

Eric Lichtfouse, Timothy Eglinton. 13C and 14C evidence of pollution of a soil by fossil fuel and reconstruction of the composition of the polluant. Organic Geochemistry, 1995, 23 (10), pp.969-973. 10.1016/0146-6380(95)00082-8 . hal-00192669

\section{HAL Id: hal-00192669 \\ https://hal.science/hal-00192669}

Submitted on 29 Nov 2007

HAL is a multi-disciplinary open access archive for the deposit and dissemination of scientific research documents, whether they are published or not. The documents may come from teaching and research institutions in France or abroad, or from public or private research centers.
L'archive ouverte pluridisciplinaire HAL, est destinée au dépôt et à la diffusion de documents scientifiques de niveau recherche, publiés ou non, émanant des établissements d'enseignement et de recherche français ou étrangers, des laboratoires publics ou privés. 
Revised version

Organic Geochemistry 23, 969-973, 1995.

doi:10.1016/0146-6380(95)00082-8

Correspondence: Dr. Eric Lichtfouse, INRA-CMSE-PME, 17, rue Sully, 21000 Dijon, France

Eric.Lichtfouse@dijon.inra.fr

\title{
${ }^{13} \mathrm{C}$ and ${ }^{14} \mathrm{C}$ evidence of pollution of a soil by fossil fuel and reconstruction of the composition of the polluant
}

\author{
ÉRIC LICHTFOUSE ${ }^{1}$ and TIMOTHY I. EGLINTON ${ }^{2}$ \\ ${ }^{1}$ Laboratoire de Biogéochimie Isotopique, associé à l'Institut National de la Recherche Agronomique, \\ Université Pierre et Marie Curie, Case 120, 75252 Paris Cx 05, France. \\ ${ }^{2}$ Marine Chemistry and Geochemistry Dept., Woods Hole Oceanographic Institution, \\ 360 Woods Hole Rd., Woods Hole, MA 02543-1543, U.S.A.
}

\begin{abstract}
Alkanes from soils in which $\mathrm{C}_{3}$ plants have been cultivated were analysed for their distributions and individual $\delta^{13} \mathrm{C}$ ratios. For long-chain $n$-alkanes from unpolluted soils, both the strong odd-carbon number predominance, with a carbon preference index (CPI) of 9.2, and the light isotope composition, $\sim-35 \%$, are typical of modern $\mathrm{C}_{3}$-plant waxes. In contrast, long-chain $n$-alkanes from another soil sample show a weak odd-carbon number predominance, with a CPI of 1.2, indicating a large anthropogenic contribution from ancient and thermally mature organic matter. This derivation from ancient organic matter is strongly supported by 1) the $\delta^{13} \mathrm{C}$ ratios of those alkanes, $\sim-30 \%$, which does not match reported values for $\mathrm{C}_{3}$ plant $n$-alkanes and which falls within the range of values reported for fossil-fuel $n$-alkanes, and 2) the ${ }^{14} \mathrm{C}$ analysis of the alkane fraction which gives an age of $8770 \mathrm{yrs}$ BP. Moreover, assuming that each soil $n$-alkane is a mixture of $\mathrm{C}_{3}$-plant $n$-alkane and fossil-fuel $n$ alkane, the isotopic composition provide a means of reconstructing the composition of the fossil fuel pollution. This method, using both isotopic and quantitative analyses of individual substances, represents a powerful means to resolve multiple sources in environmental and geochemical investigations.
\end{abstract}

Key words - carbon-13, carbon-14, soil, $n$-alkane, plant, wax, pollution, petroleum.

\section{INTRODUCTION}

$n$-Alkanes are occur widely wherever organic matter has been decomposed, such as waters, soils, sediments and coals. Although numerous studies have been undertaken to follow the fate of these substances in such complex media, many questions remain to be answered about their origin and their pathways of degradation. For instance, soil $n$-alkanes might derive from biological $n$-alkanes which are synthesized by a large variety of living organisms, such as bacteria, plants and insects (Schnitzer et al., 1986, Dinel et al., 1990, Amblès et al., 1991, 1994, and refs. therein). Moreover, a large number of living organisms, especially microbes, have not yet been analysed for $n$-alkanes and $n$-alkanes can also derive from the reduction of other aliphatic precursors such as $n$-fatty acids or $n$-alcohols. Finally, and this is rarely mentioned in the literature, $n$-alkanes of anthopogenic origin, e. g. from oil spills, may be introduced in natural systems, and can thus constitute another source. Given these possibilities, means for the recognition and reconstruction of the multiple sources of individual substances from degraded organic matter are of considerable interest. 
In recent studies at the molecular level, we have shown that ${ }^{13} \mathrm{C} /{ }^{12} \mathrm{C}$ ratios can provide information on the origins and fates of soil $n$-alkanes (Lichtfouse et al., 1994a, Lichtfouse, 1995). Furthermore, we have presented an isotopic model allowing the multiple sources of $n$-alkanes from the Green River sediments to be partially delineated (Collister et al., 1994a). Recent investigations have also shown that sources of $n$ alkanes from polluted sediments may be resolved by molecular ${ }^{13} \mathrm{C}$ analyses (Usaki et al., 1993, Ishiwatari et al., 1994). In the present work, ${ }^{13} \mathrm{C} /{ }^{12} \mathrm{C}$ ratios, ${ }^{14} \mathrm{C}$ age and relative concentrations are used to assess the origins of $n$-alkanes in a polluted soil.

\section{EXPERIMENTAL}

Soil samples, cultivated with Triticum aestivum (wheat) for the past 23 years at one crop per year, were cored in May 1993 at Boigneville, Essone, France, at various random geographical locations within the same experimental field, through the $0-30 \mathrm{~cm}$ ploughed horizon. Each 0-30 cm core was homogenised prior extraction. This field was previously cropped only with plants following the $\mathrm{C}_{3}$ photosynthetic pathway. It is a Hapludalf developed on loess (Balesdent et al., 1990). The polluted soil represents a point-source pollution. Wheat leaves were sampled at the same time, water-washed and freeze-dried at $-20^{\circ} \mathrm{C}$.

Detailed fractionation procedures are described elsewhere (Lichtfouse et al., 1994b). Careful precautions were taken to prevent contamination during the sampling and treatment of samples (solvent distillation, etc.). Briefly, alkane fractions were isolated from $\mathrm{CHCl}_{3}-\mathrm{MeOH}$ extracts $(3 / 1, \mathrm{v} / \mathrm{v})$ of dried samples by several steps of silica gel chromatography. $n$-Alkane relative concentrations were measured by area integration of peaks from alkane fractions analysed by gas chromatography using a flame ionization detector. Carbon preference indexes $(\mathrm{CPI})$ are based on relative concentrations and are calculated as follows: $\mathrm{CPI}=\left(\mathrm{C}_{25}+\mathrm{C}_{27}+\mathrm{C}_{29}+\mathrm{C}_{31}+\mathrm{C}_{33}\right) /\left(\mathrm{C}_{24}\right.$ $+\mathrm{C}_{26}+\mathrm{C}_{28}+\mathrm{C}_{30}+\mathrm{C}_{32}$ ). Isotopic analyses of individual $n$-alkanes were carried out under continuous helium flow using an HP 5890 gas chromatograph interfaced, via a $\mathrm{CuO}$ furnace $\left(850^{\circ} \mathrm{C}\right)$ and a cryogenic trap $\left(-100^{\circ} \mathrm{C}\right)$, to a $\mathrm{VG}$ Optima mass spectrometer (overall deviation 0.3\%o). Isotope compositions are expressed in per mil. relative to the Pee Dee Belemnite standard: $\delta^{13} \mathrm{C}=\left[\left({ }^{13} \mathrm{C} /{ }^{12} \mathrm{C}\right.\right.$ sample $\left.\left./{ }^{13} \mathrm{C} /{ }^{12} \mathrm{Cstd}\right)-1\right] \mathrm{x}$ $10^{3}$.

For radiocarbon analysis, about $200 \mu \mathrm{g}$ of the alkane fraction from the polluted soil, dissolved in $\mathrm{CH}_{2} \mathrm{Cl}_{2}$, were first transfered to quartz combustion tubes. Then the solvent was removed by nitrogen blow-down and evacuation of the tube. $\mathrm{CuO}$ was added, and the tubes sealed under vacuum, and the alkane fraction was converted to $\mathrm{CO}_{2}$ by combustion at $900^{\circ} \mathrm{C}$ for $5 \mathrm{hr}$. Afterwards the $\mathrm{CO}_{2}$ was reduced to graphite and pressed into targets for ${ }^{14} \mathrm{C}$ analysis by accelerator mass spectrometry (AMS) at the Lawrence Livermore National Laboratory. Radiocarbon data are reported according the convention of Stuiver and Polach (1977). The values were corrected for carbon blanks, based on AMS measurements of similar amounts of ${ }^{14} \mathrm{C}$-free coal. These data were also corrected using a $\delta^{13} \mathrm{C}$ value of $-30.1 \%$ which was calculated with relative concentions and individual $\delta^{13} \mathrm{C}$ values of $n$-alkanes. This method for ${ }^{14} \mathrm{C}$ analysis is analogous to that described in detail by Eglinton et al. (1995). 


\section{RESULTS AND DISCUSSION}

\section{Alkane distributions}

$\delta^{13} \mathrm{C}$ values and relative concentrations of $n$-alkanes from wheat leaves and two representative soils are reported in Table 1 . The distribution of $n$-alkanes in most soil samples, termed "unpolluted soils", is similar to that of wheat waxes $(\mathrm{CPI}=48.55)$, exhibiting a strong predominance of odd carbon number $n$-alkanes $(\mathrm{CPI}=9.21$, Figure 1). Since those soils have been cultivated with wheat for 23 years, soil $n$-alkanes are therefore mainly derived from wheat waxes and from earlier $\mathrm{C}_{3}$ crops. Notably, the latter contribution can be as high as $50 \%$ of each $n$-alkane, as estimated from $\delta^{13} \mathrm{C}$ values of $n$-alkanes in a portion of the field that was planted with Zea mays (maize, a $\mathrm{C}_{4}$ plant) to provide an isotopically labelled plant-wax input (Lichtfouse, 1995). The direct input of plant waxes into soils has also been demonstrated recently (Lichtfouse et al., 1994a). In contrast, one of the soil samples, termed "polluted soil", displays an $n$ alkane distribution characterized by a weak odd-carbon predominance, with a CPI of 1.17. Such a distribution is more typical of thermally mature organic matter, which is usually found in ancient sediments, coals, petroleums and kerogen pyrolysates (e.g. Tissot and Welte, 1984, Behar et al., 1984, Hofman and Leythaeuser, 1995). An input from a fossil fuel source can therefore be considered.

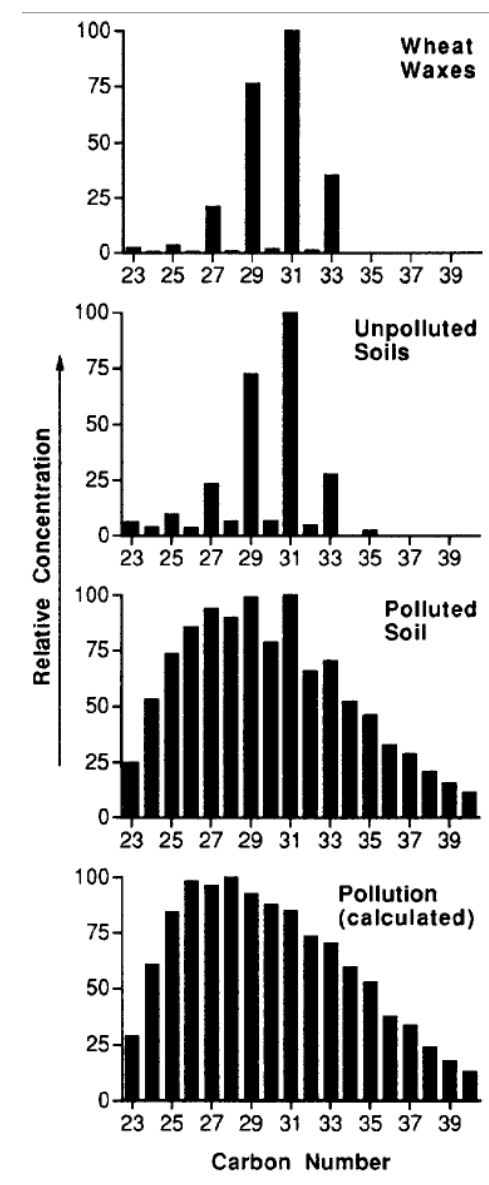

Figure 1. Distributions of $n$-alkanes from the wheat leaf waxes, from the unpolluted and polluted soils, and from the pollution source. The latter has been calculated by isotopic means (see text). 


\section{Table 1.}

$\delta^{13} \mathrm{C}$ values (\%o) and relative concentrations (\%) of $n$-alkanes from wheat leaf wax and from polluted and unpolluted soils.

\begin{tabular}{|c|c|c|c|c|c|c|c|c|c|}
\hline \multirow[t]{2}{*}{$\begin{array}{l}\text { Carbon } \\
\text { Number }\end{array}$} & \multicolumn{2}{|c|}{$\begin{array}{l}\text { Wheat } \\
\text { Waxes }\end{array}$} & \multicolumn{2}{|c|}{$\begin{array}{l}\text { Unpolluted } \\
\text { Soils }\end{array}$} & \multicolumn{2}{|c|}{$\begin{array}{c}\text { Polluted } \\
\text { Soil }\end{array}$} & \multirow[t]{2}{*}{$\mathrm{x}$} & \multicolumn{2}{|c|}{$\begin{array}{c}\text { Pollution } \\
\text { (Calculated) }\end{array}$} \\
\hline & $(\% o)$ & $(\%)$ & $\delta_{\mathrm{U}}(\% \circ)$ & $(\%)$ & $\delta_{\mathrm{P}}(\% \circ)$ & $A_{P}(\%)$ & & $\mathrm{A}_{\mathrm{F}}(\%)^{\dagger}$ & $\mathrm{A}_{\mathrm{F}}(\%)^{\ddagger}$ \\
\hline 23 & & 2.40 & & 6.09 & & 24.83 & & 24.83 & 28.54 \\
\hline 24 & & 0.66 & & 3.95 & & 52.82 & & 52.82 & 60.71 \\
\hline 25 & & 3.64 & & 9.77 & -29.5 & 73.51 & & 73.51 & 84.49 \\
\hline 26 & & 0.47 & & 3.82 & -29.5 & 85.47 & & 85.47 & 98.23 \\
\hline 27 & -35.9 & 21.28 & -34.2 & 23.25 & -30.0 & 93.98 & 0.89 & 83.64 & 96.13 \\
\hline 28 & & 0.83 & -35.5 & 6.37 & -29.7 & 89.70 & 0.97 & 87.01 & 100.00 \\
\hline 29 & -36.5 & 76.24 & -35.7 & 72.35 & -30.7 & 99.16 & 0.81 & 80.32 & 92.31 \\
\hline 30 & & 1.68 & -35.7 & 6.58 & -29.7 & 78.62 & 0.97 & 76.26 & 87.65 \\
\hline 31 & -36.7 & 100 & -35.7 & 100 & -31.1 & 100 & 0.74 & 74.00 & 85.05 \\
\hline 32 & & 1.23 & -35.6 & 4.59 & -29.7 & 65.75 & 0.97 & 63.78 & 73.30 \\
\hline 33 & -36.7 & 35.29 & -35.7 & 27.8 & -30.3 & 70.46 & 0.87 & 61.30 & 70.45 \\
\hline 34 & & & & & & 51.8 & & 51.80 & 59.53 \\
\hline 35 & & & & 2.62 & & 45.95 & & 45.95 & 52.81 \\
\hline 36 & & & & & & 32.62 & & 32.62 & 37.49 \\
\hline 37 & & & & & & 29.01 & & 29.01 & 33.34 \\
\hline 38 & & & & & & 20.78 & & 20.78 & 23.88 \\
\hline 39 & & & & & & 15.65 & & 15.65 & 17.99 \\
\hline 40 & & & & & & 11.31 & & 11.31 & 13.00 \\
\hline
\end{tabular}

${ }^{\dagger}$ Values for $\mathrm{C}_{27}-\mathrm{C}_{33}$ were calculated by isotopic means (see text). Values for other $n$-alkanes are those recorded for the polluted soil because their carbon is derived only from the pollution. ${ }^{\ddagger}$ Values normalized to $100 \%$. 
It is also notable that the polluted soil shows a slight predominance of oddcarbon-number $n$-alkanes in the $\mathrm{C}_{27}-\mathrm{C}_{33}$ range, particulary for the $\mathrm{C}_{31} n$-alkane. Since $n$-alkanes from wheat waxes and from the unpolluted soils exhibit a strong odd-carbon predominance maximizing at $\mathrm{C}_{31}$, the $n$-alkanes from the polluted soil sample are likely to represent both a small contribution from $\mathrm{C}_{3}$-plant waxes and a large contribution from fossil fuel hydrocarbons. These hypotheses are confirmed by ${ }^{13} \mathrm{C}$ and ${ }^{14} \mathrm{C}$ investigations, as explained below.

\section{Isotopic compositions of alkanes}

The ${ }^{13} \mathrm{C}$ values of $n$-alkanes from the unpolluted soils, averaging $-35.4 \pm$ $0.5 \%$, are very close to those of wheat waxes, which average $-36.5 \pm 0.3 \%$ (Figure 2) and fall within the range of isotopic compositions reported for $\mathrm{C}_{3}$ plant waxes (Collister et al., 1994b). Remarkably, even- and odd-carbon-number $n$-alkanes from the unpolluted soils have $\delta$ values that are equal within experimental error $(\sim-35.6 \%$ ). Therefore, the even- and odd-carbon-number $n$-alkanes probably have the same biological origin, e. g. they are derived from $\mathrm{C}_{3}$-plant lipids. On these isotopic grounds, and also because the distribution of $n$-alkanes in the unpolluted soils almost matches that in the wheat waxes, it can be deduced that these soil $n$-alkanes are derived from a single contemporary source, namely $\mathrm{C}_{3}$ plant waxes.

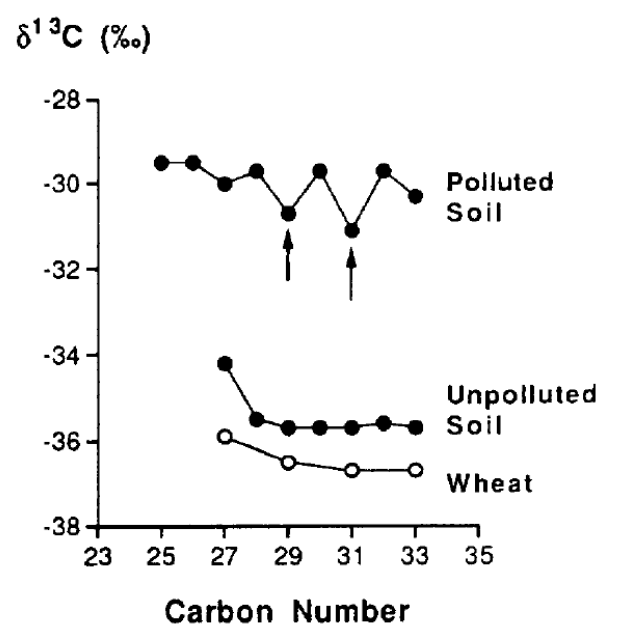

Figure 2. $\delta^{13} \mathrm{C}$ values of $n$-alkanes from soils and wheat waxes. The ${ }^{13} \mathrm{C}$-depletion of odd-carbon number $n$-alkanes from the polluted soil (arrows) indicates a partial contribution of $n$-alkanes from $\mathrm{C}_{3}$ plants, e.g. wheat.

The $\delta^{13} \mathrm{C}$ values of $n$-alkanes from the polluted soil, which average $-30.1 \%$, are markedly ${ }^{13} \mathrm{C}$-enriched, thus indicating a contribution from a source enriched in ${ }^{13} \mathrm{C}$. The $\delta$ values do not match those reported for $\mathrm{C}_{3}$ plant waxes, but fall within the range reported for sedimentary organic matter and petroleum (Kennicutt and Brooks, 1990, Lichtfouse and Collister, 1992, Clayton and Bjorøy, 1994, Freeman et al., 1994, Hartgers et al., 1994, Spooner et al., 1994, Collister et al., 1994a, Lichtfouse et al., $1994 b, c)$. Another remarkable feature of the isotopic compositions of $n$-alkanes from the polluted soil is the relative ${ }^{13} \mathrm{C}$-depletion of odd-carbon-numbered homologues, this depletion being most pronounced for the $\mathrm{C}_{31} n$-alkane (see arrows on Figure 2). Moreover, the ${ }^{13} \mathrm{C}$-depletion is associated with the odd/even predominance intensity of $n$-alkanes, e.g. the $\mathrm{C}_{31} n$-alkane is the lightest and shows the highest odd/even 
predominance (Figure 1,2). Therefore, those soil $n$-alkanes must represent a mixture of two sources, a small contribution of $\mathrm{C}_{3}$-plant $n$-alkanes with a high CPI maximizing at $\mathrm{C}_{31}$, and a large contribution from fossil fuel $n$-alkanes with a low CPI.

The alkane fraction from the polluted soil was also analysed for ${ }^{14} \mathrm{C}$. AMS dating indicated a radiocarbon age of $8770 \pm 70 \mathrm{yrs}$ before present (BP) corresponding to a fraction Modern ( $\mathrm{fM}$ ) of $\sim 0.34$. If we assume that this fraction is a mixture of modern $\mathrm{C}$ and fossil-fuel $\mathrm{C}$ (no ${ }^{14} \mathrm{C}$ ), then the fraction Modern indicates that there is only $34 \%$ of modern $\mathrm{C}$, and $66 \%$ of fossil-fuel $\mathrm{C}$. This additional evidence therefore demonstrates unambigously the occurrence of ancient carbon in $n$-alkanes from the "polluted" soil.

Utilizing the stable carbon isotopic and concentration data (Table 1), it is possible to calculate a weighted average: $100 . \Sigma(1-\mathrm{x}) \cdot \mathrm{A}_{\mathrm{P}} / \Sigma \mathrm{A}_{\mathrm{P}}$, which estimates the overall proportion of modern $n$-alkanes in the alkane fraction of the polluted soil. This calculation suggests that only $12 \%$ of the $n$-alkanes are of modern origin. This is significantly lower than that estimated based on the radiocarbon data $(34 \%)$. There are two possible reasons for this discrepancy.

First, although GC analysis of the alkane fraction was dominated by $n$-alkanes, the presence non-GC-amenable components in soil lipids was detected (Lichtfouse, unpublished results). The occurrence of non-GC-amenable components is also supported by the detection of alkanes in the range from $\mathrm{C}_{17}$ to $\mathrm{C}_{101}$ in soil humic substances using field desorption mass spectrometry (Schnitzer and Schulten, 1989, Dinel et al., 1990). Non-GC-amenable components would contribute to the ${ }^{14} \mathrm{C}$ signal (i.e. total carbon in the sample) and, if of biological origin, would give rise to a higher fM. A second explanation relates to the ${ }^{14} \mathrm{C}$ data. The fraction modern is calculated based on 1950 a.d. as "modern" (i.e. $\mathrm{fM}=1$ ). This is used because it pre-dates the injection of ${ }^{14} \mathrm{C}$ from atomic weapons testing. Carbon fixed by plants during photosynthesis later than this date will incorporate some bomb-derived ${ }^{14} \mathrm{C}$, giving rise to "greater-than-modern" values. Calculations of $\mathrm{fM}$ based on such ${ }^{14} \mathrm{C}$ measurements of such samples will thus over-estimate the \% modern carbon in the sample. Whatever the case, both independent approaches point clearly to a major contribution of fossil fuel hydrocarbons to the soil alkane fraction.

\section{Reconstruction of the pollution source signature}

To calculate the distribution of the fossil fuel source, we must determine the $\delta^{13} \mathrm{C}$ values of its $n$-alkanes. On first approximation, we estimate this value at $-29.5 \%$ o on the following grounds: 1) this is the heaviest value measured for the $n$-alkanes from the polluted soil and it must therefore represent the isotopic composition least influenced by light $n$-alkanes from $\mathrm{C}_{3}$ plants (Table 1, Figure 2) ; 2) it is the $\delta$ value for the $\mathrm{C}_{26} n$-alkane, this compound being both the least abundant among the wheat $n$ alkanes $(0.47 \%)$ and a major component of the distribution in the polluted soil $(85.47 \%)$, and 3) $\delta^{13} \mathrm{C}$ values of all even-carbon-numbered $n$-alkanes from the polluted soil, from $-29.7 \%$ o to $-29.5 \%$, are identical within the experimental error $(0.3 \%$ ), suggesting that $\delta$ values of all fossil-fuel $n$-alkanes are very similar as is usually observed for mature organic matter, petroleums and kerogen pyrolysates (Clayton and Bjorøy, 1994, Wilhelms et al., 1994, Bjorøy et al., 1994, Eglinton, 1994, Lichtfouse et 
$a l ., 1994 b)$. The latter point is also strengthened by the fact that the $\mathrm{C}_{25} n$-alkane, which should be only very weakly influenced by a plant contribution (see relative intensities on Figure 1), also has a $\delta^{13} \mathrm{C}$ value of $-29.5 \%$.

The contribution of fossil fuel to each $n$-alkane in the polluted soil can be calculated from:

$$
\mathrm{x}=\left(\delta_{\mathrm{P}}-\delta_{\mathrm{U}}\right) /\left(\delta_{\mathrm{F}}-\delta_{\mathrm{U}}\right)
$$

where $\mathrm{x}$ is the carbon fraction derived from the fossil fuel source, $\delta_{\mathrm{P}}$ is the $\delta^{13} \mathrm{C}$ value of $n$-alkane from the polluted soil, $\delta_{\mathrm{U}}$ is the $\delta^{13} \mathrm{C}$ value of the same $n$-alkane in the unpolluted soil, and $\delta_{\mathrm{F}}$ is the $\delta^{13} \mathrm{C}$ value of $n$-alkane from the fossil fuel source (here $29.5 \%$ ). Values for $\mathrm{x}$ have been calculated for $n$-alkanes in the range $\mathrm{C}_{27}-\mathrm{C}_{33}$ (Table 1 ). It is assumed, on isotopic and quantitative grounds, that other $n$-alkanes from the polluted soil derive entirely from the fossil fuel source (Figure 1, 2). The lowest $\mathrm{x}$ value, 0.74 , is observed for the $\mathrm{C}_{31} n$-alkane, indicating that this compound contains a significant contribution from $\mathrm{C}_{3}$ plants $(26 \%)$. Furthermore, the relative concentrations of $n$-alkanes in the fossil fuel source can be calculated from

$$
A_{F}=x \cdot A_{P}
$$

where $A_{F}$ is the relative concentration of an $n$-alkane in the fossil fuel-source and $A_{P}$ is the relative concentration in the polluted soil (Table 1). These calculations allow reconstruction of the original composition of the fossil fuel source (Figure 1). The calculated distribution of $n$-alkanes has no odd/even predominance (CPI $=1.02)$. This is in excellent agreement with a derivation from ancient and thermally mature organic matter (Tissot and Welte, 1984). Furthermore, the distribution maximizes at $\mathrm{C}_{28}$, indicating that the fossil fuel source could be an heavy oil. Alternatively, the light end of the fossil fuel source could have been preferentially removed by water washing and biodegradation after introduction into the soil.

\section{CONCLUSION}

Two sources of soil $n$-alkanes, a modern source from plant waxes and an ancient, anthropogenic source from fossil fuel, have been resolved using relative concentrations, $\delta^{13} \mathrm{C}$ ratios and ${ }^{14} \mathrm{C}$ age. This method represents a promising approach in environmental and geochemical studies to decipher the possible multiple origins of organic substances at the molecular level.

Acknowledgements- We are indebted to Prof. John Hayes, Indiana University, for his help to improve the manuscript. G. Bardoux is gratefuly acknowledged for technical assistance. We thank Dr. James Bauer, College of William and Mary, for assistance with the radiocarbon measurements, and we thank Dr. Michaele Kashgarian, LLNL, for access to AMS facility. This work was supported by the Institut National de la Recherche Agronomique (E. L.) and by an ASF grant (to T.I.E.) OCE-9415568. 


\section{REFERENCES}

Amblès A., Jacquesy J. C., Jambu P., Joffre J. and Maggi-Churin R. (1991) Polar lipid fraction in soil: a kerogen-like matter. Org. Geochem. 17, 341-349.

Amblès A., Parlenti E., Jambu P., Mayoungou P. and Jacquesy J.-C. (1994) n-Alkane oxidation in soil. Formation of internal monoalkenes. Geoderma 64, 111-124.

Balesdent J., Mariotti A. and Boisgontier D. (1990) Effect of tillage on soil organic carbon mineralization estimated from ${ }^{13} \mathrm{C}$ abundance in maize fields. J. Soil Sci. 41, 587-596.

Behar F., Pelet R. and Roucache J. (1984) Geochemistry of asphaltenes. Org. Geochem. 6, 587-595.

Bjorøy M., Hall P. B. and Moe R. P. (1994) Variation in the isotopic composition of single components in the $\mathrm{C}_{4}-\mathrm{C}_{20}$ fraction of oils and condensates. Org. Geochem. 21, 761-776.

Clayton C. J. and Bjorøy M. (1994) Effect of maturity on ${ }^{13} \mathrm{C} /{ }^{12} \mathrm{C}$ ratios of individual compounds in North Sea oils. Org. Geochem. 21, 737-750.

Collister J. W., Lichtfouse É., Hieshima G. and Hayes J. M. (1994a) Partial resolution of sources of $n$-alkanes in the saline portion of the Parachute Creek Member, Green River Formation (Piceance Creek Basin, Colorado). Org. Geochem. 21, 645-659.

Collister J. W., Rieley G., Stern B., Eglinton G. and Fry B. (1994b) Compoundspecific $\delta^{13} \mathrm{C}$ analyses of leaf lipids from plants with differing carbon dioxide metabolisms. Org. Geochem. 21, 619-627.

Dinel H., Schnitzer M. and Mehuys G. R. (1990) Soil lipids: origin, nature, content, decomposition, and effect on soil physical properties. In Soil Biochemistry (Edited

by Bollag J.-M. and Stotzky G.), Vol. 6, pp. 397-429. Marcel Dekker, New York.

Eglinton T. I. (1994) Carbon isotopic evidence for the origin of macromolecular

aliphatic structures in kerogen. Org. Geochem. 21, 721-735.

Eglinton T. I., Aluwihare L. I., Bauer J. E., Druffel E. R. M. and McNichol A. P. (1995) Gas chromatographic isolation of individual compounds from complex matrices for radiocarbon dating. Submitted to Analytical Chemistry.

Freeman K. H., Wakeham S. G. and Hayes J. M. (1994) Predictive isotope biogeochemistry: hydrocarbons from anoxic marine basins. Org. Geochem. 21, 629644.

Hartgers W. A., Sinninghe Damsté J. S., Requejo A. G., Allan J., Hayes J. M. and De Leeuw J. W. (1994) Evidence for only minor contributions from bacteria to sedimentary organic carbon. Nature 369, 224-227.

Hofmann P. and Leythaeuser D. (1995) Migration of hydrocarbons in carbonate source rocks of the Staßfurt member $(\mathrm{Ca} 2)$ of the Permian Zechstein, borehole Aue 1, Germany: the role of solution seams. Org. Geochem. 23, 597-606.

Ishiwatari R., Usaki M. and Yamada K. (1994) Carbon isotope composition of individual $n$-alkanes in recent sediments. Org. Geochem. 21, 801-808.

Kennicutt II M. C. and Brooks J. M. (1990) Unusual normal alkane distributions in offshore New Zealand sediments. Org. Geochem. 15, 193-197.

Lichtfouse É. (1995) ${ }^{13} \mathrm{C}$ labelling of soil $n$-hentriacontane $\left(\mathrm{C}_{31}\right)$ by maize cultivation. Tetrahedron Lett. 36, 529-530.

Lichtfouse É. and Collister J. (1992) Tracing biogenic links of natural organic substances at the molecular level with stable carbon isotopes: $n$-alkanes and $n$ alkanoic acids from sediments. Tetrahedron Lett. 33, 8093-8094. 
Lichtfouse É., Albrecht P., Behar F. and Hayes J. M. (1994b) A molecular and isotopic study of the organic matter from the Paris Basin, France. Geochim. Cosmochim.

Acta 58, 209-221.

Lichtfouse É., Derenne S., Mariotti A. and Largeau C. (1994c) Possible algal origin of long chain odd $n$-alkanes in immature sediments as revealed by distributions and carbon isotope ratios. Org. Geochem. 22, 1023-1027.

Lichtfouse É., Elbisser B., Balesdent J., Mariotti A. and Bardoux G. (1994a) Isotope and molecular evidence for direct input of maize leaf wax $n$-alkanes into crop soils. Org. Geochem. 22, 349-351.

Schnitzer M., Hindle C. A. and Meglic M. (1986) Supercritical gas extraction of alkanes and alkanoic acids from soils and humic material. Soil Sci. Soc. Am. J.

50, 913-919.

Schnitzer M. and Schulten H. R. (1989) Pyrolysis soft ionization mass spectrometry of aliphatics extracted from a soil clay and humic substances. Sci. Total Environ. 81/82, 19-30.

Spooner N., Rieley G., Collister J. W., Lander M., Cranwell P. A. and Maxwell J. R. (1994) Stable carbon isotopic correlation of individual biolipids in aquatic organisms and a lake bottom sediment. Org. Geochem. 21, 823-827.

Stuiver M. and Polach H. A. (1977) Discussion reporting of ${ }^{14} \mathrm{C}$ data. Radiocarbon 19, 355-363.

Tissot B. P. and Welte D. H. (1984) Petroleum Formation and Occurrence. Springer, Berlin.

Usaki M., Yamada K. and Ishiwatari R. (1993) Carbon isotope evidence for oil-

pollution in long chain normal alkanes in Tokyo Bay sediments. Geochem. J. 27, 385-389.

Wilhelms A., Larter S. R. and Hall K. (1994) A comparative study of the stable carbon isotopic composition of crude oil alkanes and associated crude oil asphaltene pyrolysate alkanes. Org. Geochem. 21, 751-759. 